\title{
短距離走スタートにおけるスターティングブロックに 加えられた力とブロッククリアランスの関係
}

\author{
篠原 康男1）前田 正登 ${ }^{2}$
}

Yasuo Shinohara ${ }^{1}$ and Masato Maeda ${ }^{2}$ : Relationship between the forces applied to the starting blocks and block clearance in a sprint start. Japan J. Phys. Educ. Hlth. Sport Sci. 58: 585-597, December, 2013

\begin{abstract}
The forces applied to the starting blocks are an important aspect of a sprint start. For achieving the most effective start, however, the relationship between these forces and block clearance has not been clarified. In this study, an experiment was conducted with collegiate sprinters in order to elucidate this relationship. The 19 male participants performed a start dash from the blocks as in a typical sprint race, and the forces applied to the front and rear starting blocks, as well as to the ground during the first step, were measured with force plates. The following results were obtained. Based on the impulses applied to the starting blocks, the horizontal impulse component had a greater effect than the vertical impulse component at block clearance. Furthermore, at block clearance, the horizontal component of the impulse applied to the front block accounted for a large proportion of the total horizontal impulse applied to the starting blocks. However, there was a significant correlation between the horizontal component of the impulse applied to the rear block and the total horizontal impulse applied to the starting blocks. The horizontal component of the impulse was affected by the duration of force application to the blocks. Moreover, the horizontal component of the impulse applied to the starting blocks was unrelated to block placement. This indicates that the component was affected by the position of the sprinter relative to the front and rear blocks. Lastly, the horizontal impulse component at block clearance affected the sprint start until grounding of the first step, after which this relationship differed according to the starting strategy and grounding skill of individual participants.
\end{abstract}

Key words : crouch start, starting blocks, impulse, block clearance キーワード : クラウチングスタート，スターティングブロック，力積，ブロッククリアランス

\section{I ．緒言}

陸上競技の短距離走では，クラウチングスター トでの出発とスターティングブロックの使用が義 務づけられている，選手はレース前にスターティ ングブロックの設定を調整して号砲に備え，号砲 とともに静止した構えの姿勢からブロックを離地
（以後，ブロッククリアランス）し，第 1 歩目， 第 2 歩目，‥と，徐々に加速していく．このよ うに, 静止したクラウチング姿勢から疾走速度を 一気に立ち上げるためには, スターティングブロ ックへの力発揮が必要となる. Bender（1934）

は, 短距離走スタートにおける速度獲得要因にス ターティングブロックの使用を挙げており，ま た，山根ほか（1986）のスタート方法に関する
1）神戸大学大学院人間発達環境学研究科 ·日本学術振 興会特別研究員

干657-8501 神戸市灘区鶴甲 3-11

2) 神戸大学大学院人間発達環境学研究科

干657-8501 神戸市灘区鶴甲 3-11

連絡先 篠原康男
1. Graduate School of Human Development and Environment, Kobe University

Research Fellow of the Japan Society for the Promotion of Science

3-11 Tsurukabuto Nada-ku, Kobe, Hyogo, 657-8501

2. Graduate School of Human Development and Environment, Kobe University

3-11 Tsurukabuto Nada-ku, Kobe, Hyogo, 657-8501

Corresponding author091d203d@stu.kobe-u.ac.jp 
報告によると，クラウチング姿勢からのスタート を疾走に生かせるかどうかは，筋力に起因するの ではなく, ブロックへの力の加え方が要因になる という.したがって，短距離走に打けるクラウチ ングスタートを検討する上で，スターティングブ ロックへの力発揮は重要な要因であるといえる.

スターティングブロックへの力発揮について は, 古くから研究が行われて打り（Henry， 1952), 左右のブロックにストレインゲージを貼 付することでスターティングブロックに加えられ た力の時間変化を測定するという手法が用いられ てきた（Guissard and Duchateau, 1990 ; 金子ほ か, 1976 ; 小林ほか, 1975 ; Payne and Blader, 1971 ; 佐久間 ·小林, 1980 ; 袖山ほか，1969）. しかし，ストレインゲージによる測定では，ブロ ックにストレインゲージを貼付することで，加え られた力によるブロックの歪みは測定できるもの の，ブロックに加えられた力の大きさや方向につ いて，正確かつ詳細な検討をすることはできな い。野原ほか（1977）は，スターティングブロ ックの下にフォースプレートを設置して，スター ティングブロック全体に加えられた力を測定し, スタート時の力発揮について検討を行った。その 結果，ブロックの配置設定によってブロックに加 えられた力の波形が異なっていたことを述べてい る。また，松尾（2008）は世界一流競技者 2 名 のスタート時の力波形を示し，進行方向と鉛直方 向への力の加え方が 2 名でそれぞれ異なってい たことを報告している。これらの研究から，ス ターティングブロックへの力発揮は配置や選手に よって異なるといえる.しかし，スターティング ブロック全体への力発揮が，前後それぞれのブロ ックに対する力発揮とどのように関係するのかに ついて，ほとんど議論されていない.

また，クラウチングスタートではスターティン グブロックへの力発揮のみを考えればよいという わけではない. Tellez and Doolittle (1984)は, レース全体に対し，最も貢献度の高いとされる加 速局面にはブロッククリアランスが影響すると述 べている.さらに，Mero et al. (1983)は，ス ターティングブロックへの力発揮が，その後の加
速局面に抢ける疾走速度に影響することを述べて いる. 陸上競技短距離走の指導書 (Gambetta et al., 1989）においても，よいスタートを行うため に選手が意識しなければならない点の 1 つに， ブロッククリアランスでは飛び出すのではなく, 走るようにクリアランスすることを挙げている. これらのことを踏まえると，ブロッククリアラン スは短距離走に抢けるスタートの一部であり，ス ターティングブロックへのカ発揮はクリアランス 中だけでなく，クリアランス後も踏まえたものと なる必要があろう。しかし，スターティングブロ ックヘの力発揮がブロッククリアランス後の力発 揮とどのように関係するのかについては，ほとん ど議論されていない。 小林ほか（2009）はブロ ッククリアランス後の加速局面での力発揮につい て，パフォーマンスレベル間で比較検討を行って いるが，第 1 歩目の接地以降が対象であり，ブ ロッククリアランス時の力発揮については検討し ていない. 短距離走のスタートは静止した状態か ら始まることから，スタート時の力発揮の検討に は，スターティングブロックへの力発揮も含めて 検討する必要があるといえる.

これらに対し，篠原・前田（2010）は，前後 のブロックに加えられる力および第 1 歩目の地 面反力をそれぞれフォースプレートにより測定 し，スタート時の力発揮様態について検討を行っ ている，その結果，前ブロックに加えられた力の 大きさの時間変化パターンは選手によって異な り，スタート後の第 1 歩目と関係する可能性が あることを報告している。しかし，この報告で は，加えられた力の時間変化パターンについて検 討しているのみで，前後それぞれのブロックやス ターティングブロック全体への力発揮，ブロック クリアランス後の第 1 歩目への影響について, 詳細な検討はなされていない.

さらに，スターティングブロックへの力発揮を 力積の観点から論じたものも少ない．野原ほか （1977）は，クリアランス時の速度はブロックに 加えられた一時点の力の大小よりも，加えられた 力のトータルである力積に支配されると述べてい る. Fortier et al. (2005) は, 前後のブロックに 
加えられた力の波形や力の最大值，力を加えた時 間などの測定データを選手にフィードバックする ことでスタート動作のスキル改善を試みたが，フ ィードバック後の改善はみられなかったことを報 告している．これらのことから，ある一時点の力 の大きさよりも, 力と時間の積である力積を観点 とした方が，スタート時の力発揮を検討すること に則しているといえる，さらに，選手によってス タートの運動感覚やイメージが異なるという報告 （戸倉·佐藤，2009）もみられることから, 前後 それぞれのブロックやスターティングブロック全 体に加えられる力積の大きさやその加え方は一定 であるとは考えにくい。したがって，ブロックク リアランス中に加えられた力積の大きさからス ターティングブロックへのカ発揮がブロッククリ アランスとどのように関係するのかを検討する必 要があろう.

本研究では, 短距離走スタート時の力発揮につ いて, 特に静止した状態から加速する際の力発揮 に着目し，スターティングブロックヘの力発揮の 大きさがブロッククリアランスやその後の第 1 歩目とどのように関係するか, スターティングブ ロックに加えられた力積をもとに検討することを 目的とした.

\section{II. 方 法}

\section{1. 被験者}

被験者は, 大学陸上競技部に所属する男子短距 離選手19名（身長; $172.8 \pm 5.3 \mathrm{~cm}$, 体重; 64.4 $\pm 4.5 \mathrm{~kg}, 100 \mathrm{~m}$ 走自己記録；11.18 \pm 0.30 秒 : 記録の範囲は10.62-11.75秒）とした。なお, 被 験者には実験前に研究の目的, 実験方法および測 定時の危険性などについて十分に説明を行った 後, 実験参加の了解を得た. 実験は, 「神戸大学 大学院人間発達環境学研究科に抢ける人を直接の 対象とする研究に関する規程」に則り行われた.

\section{2. 実験方法}

1) 測定機器の設定

本研究では左右それぞれのブロックに加えられ

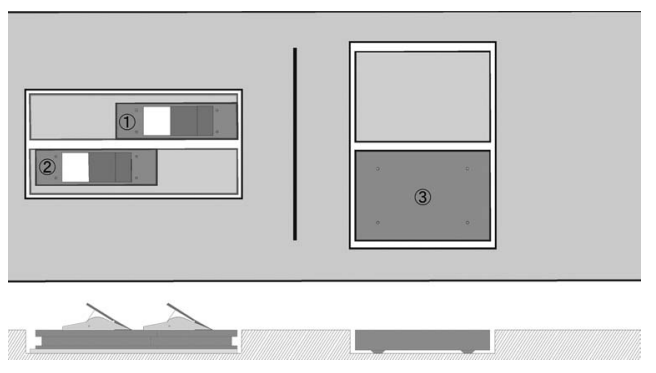

図 1 各フォースプレートの配置設定

る力を測定するために左右のブロックを固定する フレームを取り外し, 左右のブロックを独立させ て 2 台のフォースプレート (TP803-5416-5KN, テック技販）上にそれぞれボルトで完全に固定し た（図 1 参照, (1) と(2)が該当). 左右のフォース プレート間は, フレーム幅と同じ距離に設定し た. 左右のブロックは，それぞれフォースプレー トに取り付けたまま $3.5 \mathrm{~cm}$ 間隔で前後に移動さ せて設置することが可能であり, 通常のスターテ イングブロックと変わらない配置設定ができるよ うにした。

また, 本研究ではスタート後の第 1 歩目の地 面反力についても, スターティングブロックに加 えられた力とは別にフォースプレート (9281C,

Kistler）を用いて測定を行った（図 1 参照, (3) が該当).

\section{2）実験試技}

被験者には, 競技会を想定したスターティング ブロックからのスタートダッシュを行わせた. そ の際, 被験者には第 4 歩目屯では競技会の意識 でスタートするように指示し， $7 \mathrm{~m}$ 程度以上を疾 走させた. また，試技を行う前に，普段と同じブ ロック配置となるようフォースプレートの位置を 調節した. なお, 各ブロックの角度および足の着 き方については, 普段と同様の設定にするように 被験者に指示した．被験者のブロッククリアラン ス時に後ブロック，前ブロックに加えられた力お よび第 1 歩目の地面反力を測定した. 試技回数 は10回とし，試技間は疲労の影響が出ないよう に選手に確認をとってから次の試技に移ることと した. 3 つのフースプレートに㧍けるサンプリ 


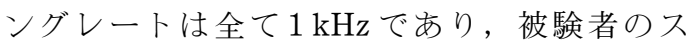
タートダッシュの合図には JESTAR（ニシ・ス ポーツ）を用い，フォースプレートからの信号出 力を収録する際の外部トリガーとしても用いた。

\section{3. 試技分析}

本研究では, 前後のブロックに加えられた力お よび第 1 歩目の地面反力について，号砲前 0.1 秒 から第 1 歩目を離地するまでを分析対象とした.

1）分析項目

(1) 力積 $(\mathrm{Ns} / \mathrm{kg})$

ブロッククリアランス中に前後のブロックに加 えられる力は, 主に進行方向と逆方向拈よび鉛直 下向きの力と考えることができる，そこで，ス ターティングブロックに加えられた力積の水平成 分および鉛直成分を前後のブロック別にそれぞれ 求めた（以下，「前ブロックへの力積（水平成分： $I_{F h}$, 鉛直成分 $\left.: I_{F v}\right) 」$ と「後ブロックへの力積 (水平成分 $: I_{R h}$, 鉛直成分 $\left.: I_{R v}\right) 」$ と略す). とし て，成分ごとに加算し，スターティングブロック
に加えられた力積の水平成分抢よび鉛直成分をそ れぞれ算出した（以下，「スターティングブロッ クへの力積（水平成分 : $I_{T h}$, 鉛直成分 $\left.: I_{T v}\right) 」$ と 略す)。なお，ブロッククリアランス中に加えら れた力積の鉛直成分については，Set 時に前ブロ ックおよび後ブロックに加えられている鉛直成分 の力の平均值を基準（Baseline）とし，号砲後， 鉛直成分に加えられた力から Baseline 分を差し 引いた值を用いて算出した。

また，第 1 歩目については，第 1 歩目の接地 中に加えられた力積を水平成分抢よび鉛直成分に それぞれ分けて算出した（以下，「第 1 歩目の力 積（水平成分 : $I_{G h}$, 鉛直成分 $\left.: I_{G v}\right) 」$ と略す). なお，加えられた力積の鉛直成分については，体 重分を差し引いた值として算出した.

全ての力積は被験者の体重で除した值とした.

(2) 力を加えた時間 ( $\mathrm{s})$

Set の構え時における水平成分と鉊直成分の合 成力を基準 (Baseline) とした。 そして，号砲後， 合成力が Baseline を100\%とした時の105\%を上

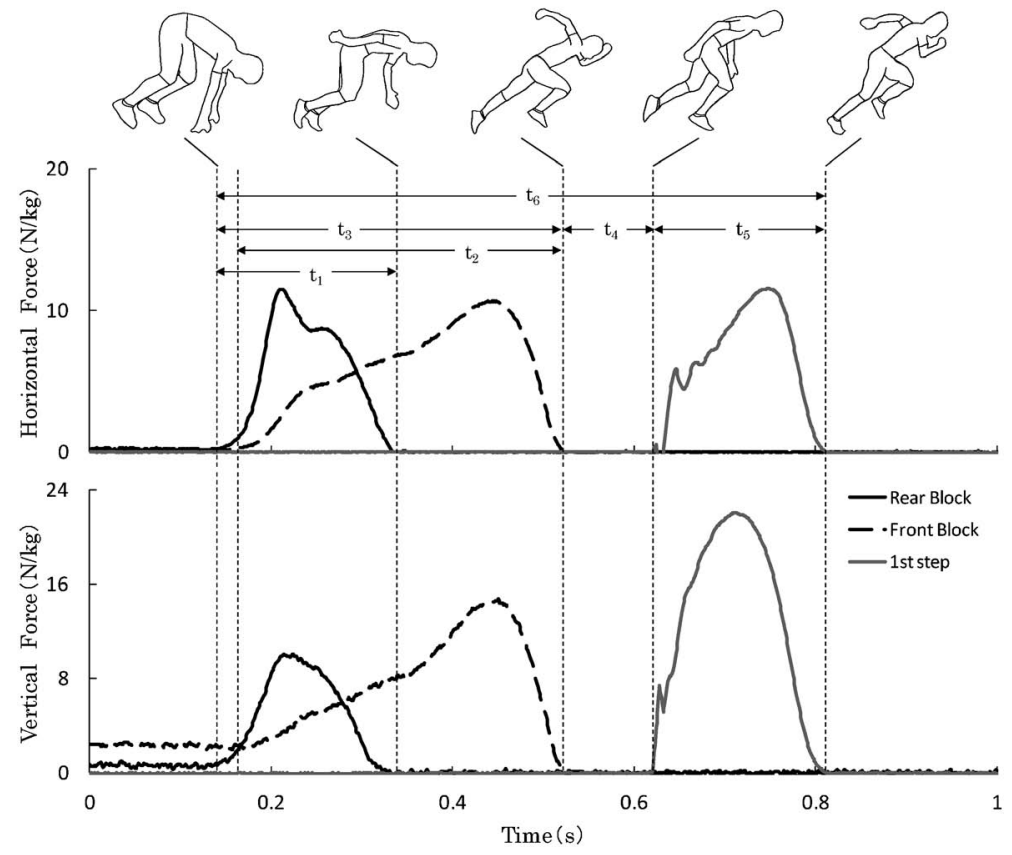

図 2 本研究に抢ける時間に関する分析項目の定義

$\left(t_{1}\right.$ : 後ブロック時間, $t_{2}$ : 前ブロック時間, $t_{3}$ : ブロッククリアランスタイム, $t_{4}$ : 滞空時間, $t_{5}:$ 第 1 歩目の接地時間, $\mathrm{t}_{6}:$ 第 1 歩目離地までの時間) 
回った時点をブロックに力が加えられ始めた時点 とした．また，ブロックに力が加えられ始めた時 点から足がブロックを離地するまでの時間を前後 のブロック別にそれぞれ求め, ブロックにカが加 えられた時間とした（以下，「後ブロック時間： $\mathrm{t}_{1} 」$ および「前ブロック時間 $: \mathrm{t}_{2} 」$ と略す，図 2 参照). また, 前後どちらかのブロックに力が加 えられ始めた時点から前足が前ブロックを離地す るまでのブロッククリアランス全体に要した時間 (以下,「ブロッククリアランスタイム $: \mathrm{t}_{3} 」$ と略 す）も求めた。な㧍，これらの分析項目はČoh et al. (1998) やFortier et al. (2005)の報告を参 考に算出した。さらに，第 1 歩目については， 第 1 歩目を接地してから離地するまでの時間を 求めた（以下，「第 1 歩目の接地時間 : $t_{5} 」$ と略 す).

(3) 滞空時間 (s)

ブロッククリアランス（前ブロックを離地）し てから，第 1 歩目を接地するまでに要した時間 を滞空時間 : $t_{4}$ として求めた.

(4) 第 1 歩目を離地するまでの時間（s）

前後どちらかのブロックに力が加えられ始めて から, 第 1 歩目を離地するをでの時間を求めた (以下,「第 1 歩目離地までの時間 : $\mathrm{t}_{6}$ 」と略す).

(5) 平均力 $(\mathrm{N} / \mathrm{kg})$

ブロッククリアランス中に加えられた力積 (1) を参照）と力を加えた時間 (2)を参照)を用いて， ブロッククリアランス中に加えられた力の平均值 を平均力 (以下, 「後ブロック平均力」,「前ブロ ック平均力」抢よび「スターティングブロック平 均力」と略す）として算出した.

(6) 前後のブロック配置 (cm)

スタートラインから前後のブロック位置までの 距離（以下,「前距離」抢よび「後距離」と略す） と前後のブロックの間隔（以下，「ブロック間距 離」と略す）をそれぞれ実測した。

2) 統計処理

各試技の分析により得られた各データは，10 試技分を加算平均したものを被験者の代表值とし た. 各分析項目間の関係について，それぞれピア ソンの積率相関係数を用いて検討し, 有意水準を
$5 \%$ 未満とした。また，各被験者の代表値を用い た平均值の比較には, 対応のある $\mathrm{t}$ 検定を用い て，有意水準 $5 \%$ で検定を行った.

\section{III. 結 果}

表 1 に，ブロッククリアランス中に加えられ た力積の水平成分と鉛直成分の平均值と標準偏差 を示す. スターティングブロックへの力積の水平 成分 $\left(I_{T h}\right)$ と鉛直成分 $\left(I_{T v}\right)$ との間には有意な 差が認められ, 水平成分 $\left(I_{T h}\right)$ の方が有意に大 きい值を示していた（p<0.01）。 また，後ブロッ クおよび前ブロックへの力積においても, 水平成 分 $\left(I_{R h}\right.$ と $\left.I_{F h}\right)$ の方が鉛直成分 $\left(I_{R v}\right.$ と $\left.I_{F v}\right)$ に比 べて，それぞれ有意に大きい值を示していた（p $<0.01)$.

表 2 に, ブロッククリアランス中に前後のブ ロックに加えられた力積の水平成分の平均值と標 準偏差, 最大值および最小值を示す。なお，最大 值および最小值は, 対象としたそれぞれの被験者 ごとの值である. 後ブロックへの力積 $\left(I_{R h}\right)$ と 前ブロックへの力積 $\left(I_{F h}\right)$ との間には有意な差

表 1 ブロッククリアランス中に加えられた力積の水 平成分および鉛直成分の比較

\begin{tabular}{ccc}
\hline & \multicolumn{2}{c}{ 力積 $(\mathrm{Ns} / \mathrm{kg})$} \\
\cline { 2 - 3 } & 水平成分 & 鉛直成分 \\
\hline スターティングブロック & $3.04 \pm 0.14^{* *}$ & $2.68 \pm 0.11$ \\
後ブロック & $0.92 \pm 0.24^{* *}$ & $0.69 \pm 0.20$ \\
前ブロック & $2.13 \pm 0.21^{* *}$ & $1.99 \pm 0.21$ \\
\hline & 水平 $>$ 鉛直, & $* * \mathrm{p}<0.01$
\end{tabular}

表 2 ブロッククリアランス中に前後のブロックに加 えられた力積の水平成分の比較

\begin{tabular}{ccc}
\hline & \multicolumn{2}{c}{ 力積 $(\mathrm{Ns} / \mathrm{kg})$} \\
\cline { 2 - 3 } & $\begin{array}{c}\text { 後ブロック } \\
\left(I_{R h}\right)\end{array}$ & $\begin{array}{c}\text { 前ブロック } \\
\left(I_{F h}\right)\end{array}$ \\
\hline 平均值 $(\mathrm{n}=19)$ & $0.92 \pm 0.24$ & $2.13 \pm 0.21^{* *}$ \\
最大值 $(\mathrm{n}=19)$ & 1.34 & 2.63 \\
最小值 $(\mathrm{n}=19)$ & 0.38 & 1.78 \\
\hline
\end{tabular}

後ブロック<前ブロック, ${ }^{* *} \mathrm{p}<0.01$ 
が認められ $(\mathrm{p}<0.01)$, 前ブロックへの力積 $\left(I_{F h}\right)$ の方が有意に大きい值を示していた。ま た，最大值と最小值ともに前ブロックの方が後ブ ロックよりも加えられた力積は大きかった.さら に, 後ブロックへの力積の最大值は, 前ブロック への力積の最小值を上回ることはなかった．

図 3 に，ブロッククリアランス中に加えられ た各水平成分力積の関係を示す．後ブロックへの 力積の水平成分 $\left(I_{R h}\right)$ とスターティングブロッ クへの力積の水平成分 $\left(I_{T h}\right)$ との間には，有意 な正の相関関係 $(\mathrm{r}=0.473, \mathrm{p}<0.05)$ が認めら
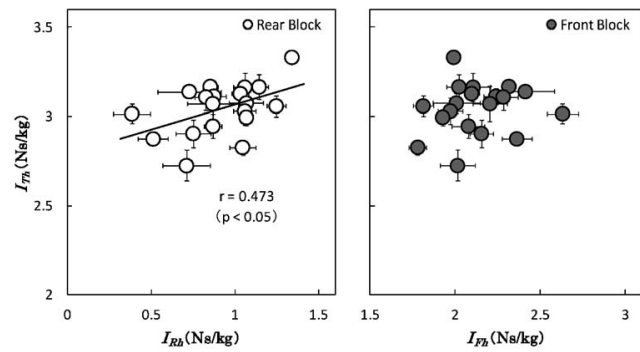

図 3 ブロッククリアランス中に加えられた各水平成 分力積の関係
れた.しかし，前ブロックへの力積の水平成分 $\left(I_{F h}\right)$ とスターティングブロックヘの力積の水平 成分 $\left(I_{T h}\right)$ との間には，有意な相関関係は認め られなかった。

ブロッククリアランス中に加えられた力積の水 平成分とブロッククリアランス中に力が加えられ た時間との相関係数を表 3 に示す。後ブロック への力積の水平成分 $\left(I_{R h}\right)$ と後ブロック時間 $\left(\mathrm{t}_{1}\right)$ との間には有意な正の相関関係が認められた（r $=0.569, \mathrm{p}<0.05)$. また， スターティングブロ ックへの力積の水平成分 $\left(I_{T h}\right)$ と後ブロック時 間（ $\left.t_{1}\right)$ およびブロッククリアランスタイム $\left(t_{3}\right)$ との間にも有意な正の相関関係が認められた（後 ブロック時間 : $\mathrm{r}=0.467, \mathrm{p}<0.05$; ブロックク リアランスタイム $: \mathrm{r}=0.497, \mathrm{p}<0.05)$. さら に，有意な相関関係ではなかったものの，スター ティングブロックへの力積の水平成分 $\left(I_{T h}\right)$ と 前ブロック時間（ $\left.t_{2}\right)$ との間には有意となる傾向 （力積 : $\mathrm{r}=0.448, \mathrm{p}=0.055 ）$ がみられた. その 他の項目間の関係については，いずれも有意な相 関関係は認められなかった。

ブロッククリアランス中に加えられた力積の水

表 3 ブロッククリアランス中に加えられた力積の水平成分とブロッククリアランス中にカが加えられた時間との 相関係数

\begin{tabular}{cccc}
\hline 加えられたカ積の水平成分 & $\begin{array}{c}\text { 後ブロック時間 } \\
\left(\mathrm{t}_{1}\right)\end{array}$ & $\begin{array}{c}\text { 前ブロック時間 } \\
\left(\mathrm{t}_{2}\right)\end{array}$ & $\begin{array}{c}\text { ブロッククリアランスタイム } \\
\left(\mathrm{t}_{3}\right)\end{array}$ \\
\hline $\begin{array}{c}\text { スターティングブロック } \\
\left(I_{T h}\right)\end{array}$ & $0.467^{*}$ & $0.448^{\dagger}$ & $0.497^{*}$ \\
$\begin{array}{c}\text { 後ブロック } \\
\left(I_{R h}\right) \\
\text { 前ブロック } \\
\left(I_{F h}\right)\end{array}$ & $0.569^{*}$ & $0.111^{\text {n.s. }}$ & $0.057^{\text {n.s. }}$ \\
& $-0.326^{\text {n.s. }}$ & $0.176^{\text {n.s. }}$ & $0.269^{\text {n.s. }}$ \\
\hline
\end{tabular}

${ }^{*} \mathrm{p}<0.05,{ }^{\dagger} \mathrm{p}=0.055$, n.s.: no significant

表 4 ブロッククリアランス中に加えられた力積の水平成分とブロッククリアランス中の平均力との相関係数

\begin{tabular}{cccc}
\hline 加えられた力積の水平成分 & 後ブロック平均力 & 前ブロック平均力 & スターティングブロック平均力 \\
\hline $\begin{array}{c}\text { スターティングブロック } \\
\left(I_{T h}\right)\end{array}$ & $0.267^{\text {n.s. }}$ & $-0.237^{\text {n.s. }}$ & $0.005^{\text {n.s. }}$ \\
後ブロック \\
$\begin{array}{c}\left(I_{R h}\right) \\
\text { 前ブロック } \\
\left(I_{F h}\right)\end{array}$ & $0.819^{* *}$ & $-0.708^{* *}$ & $0.199^{\text {n.s. }}$ \\
& $-0.742^{* *}$ & $0.637^{* *}$ & $-0.220^{\text {n.s. }}$ \\
\hline
\end{tabular}


表 5 ブロッククリアランス中に加えられた力積の水平成分とブロック配置の相関係数

\begin{tabular}{|c|c|c|c|}
\hline 加えられた力積の水平成分 & ブロック間距離 & 前距離 & 後距離 \\
\hline スターティングブロック & $0.077^{\text {n.s. }}$ & $-0.285^{\text {n.s. }}$ & $-0.125^{\text {n.s. }}$ \\
\hline $\begin{array}{c}\text { 後ブロック } \\
\left(I_{R h}\right)\end{array}$ & $-0.095^{\text {n.s. }}$ & $-0.273^{\text {n.s. }}$ & $-0.329^{\text {n.s. }}$ \\
\hline $\begin{array}{c}\text { 前ブロック } \\
\left(I_{F h}\right)\end{array}$ & $0.158^{\text {n.s. }}$ & $0.116^{\text {n.s. }}$ & $0.286^{\text {n.s. }}$ \\
\hline
\end{tabular}

n.s.: no significant
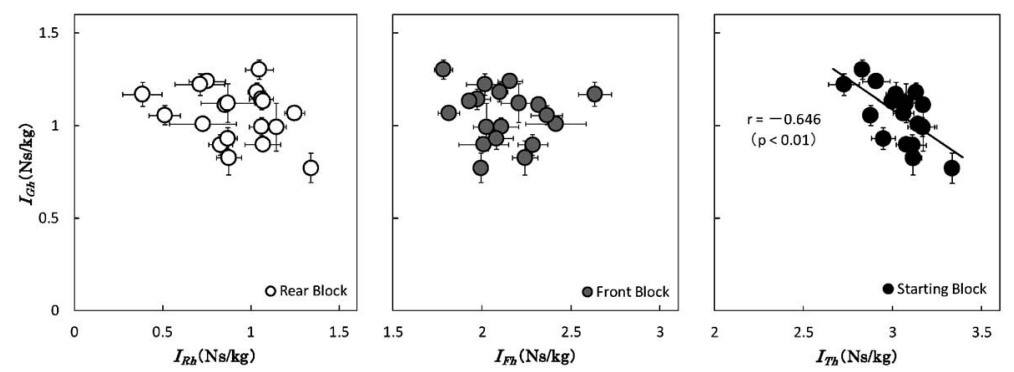

図 4 ブロッククリアランス中に加えられた力積の水平成分と第 1 歩目の力積の水平成分の関係
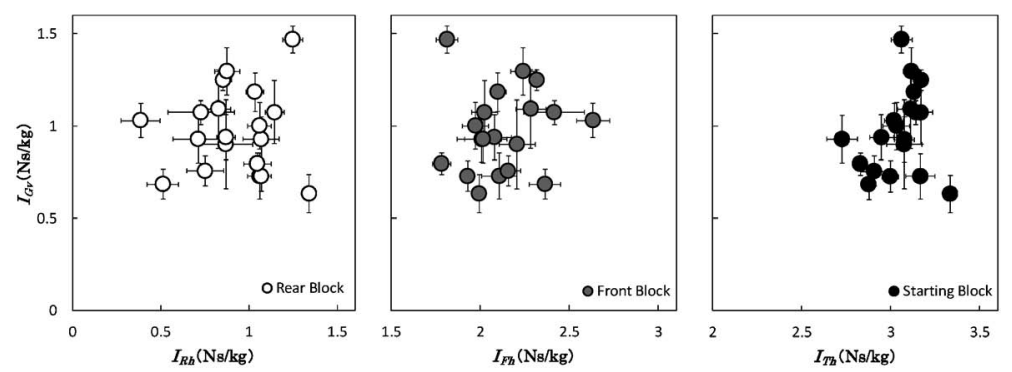

図 5 ブロッククリアランス中に加えられた力積の水平成分と第 1 歩目の力積の鉛直成分の関係

平成分とブロッククリアランス中の平均力との相 関係数を表 4 に示す. 後ブロックへの力積の水 平成分 $\left(I_{R h}\right)$ と後ブロック平均力抢よび前ブロ ック平均力との間に有意な相関関係が認められた (後ブロック平均力 $: \mathrm{r}=0.819, \mathrm{p}<0.01$; 前ブロ ック平均力 $: \mathrm{r}=-0.708, \mathrm{p}<0.01)$. また, 前ブ ロックへの力積の水平成分 $\left(I_{F h}\right)$ と後ブロック 平均力および前ブロック平均力の間にもそれぞれ 有意な相関関係が認められた（後ブロック平均 力 $: \mathrm{r}=-0.742, \mathrm{p}<0.01$; 前ブロック平均力 $: \mathrm{r}$ $=0.637, \mathrm{p}<0.01)$. 一方, スターティングブロ ックへの力積の水平成分 $\left(I_{T h}\right)$ と後ブロック平
均力, 前ブロック平均力, スターティングブロッ ク平均力との間には, いずれも有意な相関関係は 認められなかった。

ブロッククリアランス中に加えられた力積の水 平成分とブロック配置の相関係数を表 5 に示 す．後ブロック，前ブロックおよびスターティン グブロックへの力積の水平成分 $\left(I_{R h}, I_{F h}, I_{T h}\right)$ とブロック間距離, 前距離および後距離との間に は，いずれも有意な相関関係は認められなかった。

図 4 に，ブロッククリアランス中に加えられ た力積の水平成分と第 1 歩目の力積の水平成分 との関係を示した．後ブロックおよび前ブロック 
表 6 ブロッククリアランス中に加えられた力積の水平成分とブロッククリアランス後の各時間との相関係数

\begin{tabular}{|c|c|c|c|}
\hline 加えられた力積の水平成分 & $\begin{array}{c}\text { 帯空時間 } \\
\left(\mathrm{t}_{4}\right)\end{array}$ & $\begin{array}{c}\text { 第 } 1 \text { 歩目の接地時間 } \\
\left(\mathrm{t}_{5}\right)\end{array}$ & $\begin{array}{c}\text { 第 } 1 \text { 歩目離地までの時間 } \\
\left(\mathrm{t}_{6}\right)\end{array}$ \\
\hline スターティングブロック & $-0.020^{\text {n.s. }}$ & $0.049^{\text {n.s. }}$ & $0.398^{\text {n.s. }}$ \\
\hline $\begin{array}{c}\text { 後ブロック } \\
\left(I_{R h}\right)\end{array}$ & $0.560^{*}$ & $-0.261^{\text {n.s. }}$ & $0.170^{\text {n.s. }}$ \\
\hline $\begin{array}{c}\text { 前ブロック } \\
\left(I_{F h}\right)\end{array}$ & $-0.643^{* *}$ & $0.326^{\text {n.s. }}$ & $0.076^{\text {n.s. }}$ \\
\hline
\end{tabular}

${ }^{*} \mathrm{p}<0.05,{ }^{* *} \mathrm{p}<0.01$, n.s.: no significant
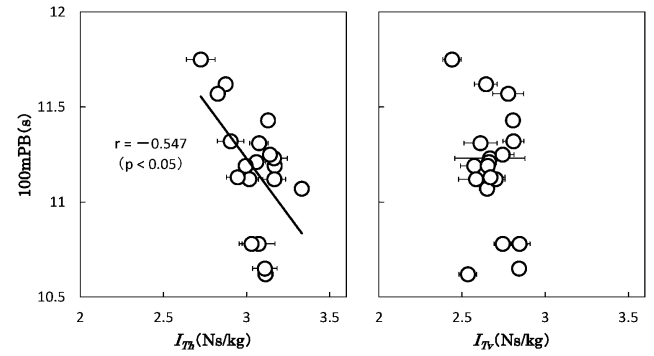

図 6 ブロッククリアランス中に加えられた力積と 100 $\mathrm{m}$ 走自己記録の関係

（左：水平成分，右：鉛直成分）

への力積の水平成分 $\left(I_{R h}, I_{F h}\right)$ と第 1 歩目の力 積の水平成分 $\left(I_{G h}\right)$ との間には有意な相関関係 は認められなかったが，スターティングブロック への力積の水平成分 $\left(I_{T h}\right)$ と第 1 歩目の力積の 水平成分 $\left(I_{G h}\right)$ との間には有意な負の相関関係 が認められた $(\mathrm{r}=-0.646, \mathrm{p}<0.01)$.

図 5 に，ブロッククリアランス中に加えられ た力積の水平成分と第 1 歩目の力積の鉛直成分 との関係を示す．後ブロック，前ブロックおよび スターティングブロックへの力積の水平成分 $\left(I_{R h}, I_{F h}, I_{T h}\right)$ と第 1 歩目の力積の鉛直成分 $\left(I_{G v}\right)$ との間には，いずれも有意な相関関係は認 められなかった。

ブロッククリアランス中に加えられた力積の水 平成分とブロッククリアランス後の各時間との相 関係数を表 6 に示す。後ブロックおよび前ブロ ックへの力積の水平成分 $\left(I_{R h}, I_{F h}\right)$ と滞空時間 $\left(\mathrm{t}_{4}\right)$ との間には, 後ブロックでは正の, 前ブロ ックでは負の有意な相関関係が認められた（後ブ
ロック $: \mathrm{r}=0.560, \mathrm{p}<0.05 ;$ 前ブロック $: \mathrm{r}=$ $-0.643, \mathrm{p}<0.01)$. その他の項目間の関係につ いては，いずれも有意な相関関係は認められなか った。

図 6 に，ブロッククリアランス中に加えられ た力積と $100 \mathrm{~m}$ 走自己記録の関係を示す. スター ティングブロックへの力積の水平成分 $\left(I_{T h}\right)$ と $100 \mathrm{~m}$ 走自己記録の間には有意な相関関係が認め られた $(\mathrm{r}=-0.547, \mathrm{p}<0.05)$. 一方, スターテ イングブロックへの力積の鉛直成分 $\left(I_{T v}\right)$ と 100 $\mathrm{m}$ 走自己記録の間には有意な相関関係は認めら れなかった。

\section{N. 考察}

\section{1. スターティングブロックへのカ発揮成分}

表 1 より，スターティングブロックへの力積 の水平成分は鉛直成分よりも有意に大きかった. これは，後ブロックおよび前ブロックでも同様の 結果であった，Baumann（1976）は，短距離走 スタートに拈いて，良いスタートは水平方向への 力発揮によって特徵づけられると述べている. 野 原ほか（1977）も，ブロックに加えられた力の 水平成分がスタートの飛び出しに大きく影響する ものと捉えている. Coppenolle et al. (1990) や Čoh et al. (1998)の先行研究でも, ブロックに加 えられた力の水平成分（進行方向の成分）に着目 して分析を行っている. 本研究の結果をみても, ブロッククリアランスに抢ける力発揮では水平成 分は鉛直成分よりも有意に大きかった。 また， Coppenolle et al. (1990) はクリアランス時点での 
疾走速度をスターティングブロックヘ加えた力積 により生じたものと捉えている．これらのことを 踏まえると, ブロッククリアランスにおける力発 揮は水平成分の力積によって特徵づけられるもの と考えられる.

\section{2. スターティングブロックに加えられた力積 とブロッククリアランスの関係}

表 2 より，いずれの選手に打いても，前ブロ ックへの力積の水平成分は, 後ブロックへの力積 の水平成分より大きかった。 Guissard and Duchateau (1990) の報告でも, スターティング ブロックへの力積に占める割合は前ブロックの方 が高かったことを報告している、本研究の結果か らも, スターティングブロックへの力積の大きさ に対する割合は前ブロックの方が高いといえる. また，スターティングブロックへの力積は，クリ アランス速度の大きさにほぼ直結する（Coppenolle et al., 1990) と言われている. Kistler （1934）は，スタート時の前後のブロックへの力 発揮の配分から, スタート時の推進力の大部分は 前脚によるものであったと報告し, Henry (1952) も, クリアランス速度には前脚の方がより貢献す るとしている. しかし, 前ブロックへの力積の水 平成分とスターティングブロックヘの力積の水平 成分との間には，有意な相関関係が認められなか った（図 3). 一方, 後ブロックでは, スターテ イングブロックへの力積の水平成分との間に有意 な相関関係が認められた $(\mathrm{r}=0.473, \mathrm{p}<0.05)$.

スターティングブロックへの力積の大きさに対す る割合は前ブロックの方が高いものの, 後ブロッ クへの力積の方が，スターティングブロックへの 力積の大きさに影響していた．このような関係が みられた背景には，ブロッククリアランス時に前 後のブロックをどのように用いるかというクリア ランス技法が関係しているものと考えられる.

クラウチングスタートに抢けるブロッククリア ランス時の力発揮に関する技術指導では, 力を加 える時間が長い前ブロックへの力発揮が特に重要 である（エッカー，1979）と言われている。一 方, 後ブロックについては, 号砲とともにブロッ
クを押す方がよい（シュモリンスキー，1982； 遠藤，1980）とする見解の一方で, ほとんど押 さずに後足を素早く前方に引き付ける（湯浅, 1976 ; エッカー, 1979 ; Mach, 1985) 方がよい という見解もあり, 指導書によってその見解は異 なっている。このように異なる見解がみられるこ とについて, Harland and Steele (1997) は,「Set」 の構えから疾走動作に早く移るためには，できる 限り早く後足を前方へ引き上げなければならず, その際に後ブロックを押した反作用で足を引き上 げる方法と, 後ブロックを押さずに後足を引きつ けることで足を引き上げる方法があるとしてい る. 後ブロックのクリアランス技法に関しては, 西内（1979）は，短距離走のスタートでは多く の選手が後ブロックを強く蹴る方法をとっている と述べているが, 他方で, 片尾（1973）は, ス タートの際に短距離選手は出発動作々前足に意識 を集中している傾向があることを報告しており， 後ブロックを強く蹴ることがない選手もいる可能 性を示唆している，後ブロックを押す，あるいは ほとんど押さずに後足を素早く前方に引き付ける といった 2 つ技法について，それらを加えら れた力積の大小として捉えると, 本研究の被験者 の後ブロックのクリアランスは, 2 種類の技法に 明確に分かれるものではなく，被験者によってク リアランスが様々であったと考えられる。これら のことで, 後ブロックへの力積の大きさの大小が 被験者によって異なり，スターティングブロック への力積の大きさの大小に影響したものと考えら れる。

また, 表 3 よりスターティングブロックへの 力積の水平成分は後ブロック時間と有意な正の相 関関係（ $\mathrm{r}=0.467, \mathrm{p}<0.05 ）$ であった. Guissard and Duchateau (1990) は, 彼らの研究で対 象とした選手達でのスターティングブロックに加 えられた力積の水平成分が，Baumann（1976） の報告した值に比べて低かったのは, Baumann （1976）が対象とした選手達の方が後ブロックに 力を加える時間が長かったことによるものである と述べている。これらのことを踏まえると，ス ターティングブロックへの力積の大小は, 後ブロ 
ックを押す時間の長さによって影響を受けるもの と考えられる.さらに，スターティングブロック への力積の水平成分は，ブロッククリアランスタ イムとも有意な正の相関関係 $(\mathrm{r}=0.497, \mathrm{p}<$ 0.05）があり，前ブロック時間とも有意となる傾 向 $(\mathrm{r}=0.448, \mathrm{p}=0.055)$ を示した. また，表 4 より，スターティングブロックへの力積の水平成 分は, 前後のブロックおよびスターティングブロ ックの平均力のいずれとも有意な相関関係が認め られなかった。したがって，ブロッククリアラン スに抢けるスターティングブロックへの力積の大 きさの大小は，スターティングブロックに加えら れた力の大小よりも力を加える時間の長さにより 影響を受けるものであると考えられる.

\section{3. スターティングブロックに加えられた力積 と Set 時のブロック配置の関係}

短距離競走の発走では，選手は静止した状態か ら号砲とともにブロックへと力を加え，クリアラ ンスを行うことになる。したがって，ブロックへ の力発揮には, ブロック配置が少なからず関係す るものと考えられる。しかし，スターティングブ ロックに加えられた力積の水平成分とブロック配 置の間には，有意な相関関係は認められなかった (表 5). ブロックへの力発揮とブロック配置の関 係に関する研究（Kistler, 1934; Henry, 1952 ; 野 原ほか，1977）によると，ブロック配置によっ てはブロックへの力発揮が変わることが報告され ている、このことについては, 先行研究ではブロ ック配置をバンチ，ミディアム，エロンゲーテッ ドといったように，配置を数種類に分類した上で それらの間で比較検討しているものが多い。一 方, 本研究では, スターティングブロックに加え られた力積の大きさを用いてブロック配置との関 係を検討しており, 先行研究と本研究では検討方 法が異なっている.

また，前後のブロック配置の仕方により， Set 時の構えの姿勢は打打よそ決まるといえるが，ス タートラインに手をついた時の腕の角度（Schot and Knutzen，1992）や各ブロックへの荷重配分 によって，同じブロック配置でも構えの姿勢は異
なることが考えられる。このことについて，一川 ほか（2006）は，スターティングブロックの配 置は選手自身の構えやすさに任せて設定されてい る傾向が強いことを報告している。本研究で対象 とした被験者のブロック間距離の設定は $20 \mathrm{~cm}$ 前 後が比較的多く, 表 5 の結果と合わせて考える と, 選手によって前後のブロックと身体との相対 的な位置関係をそれぞれに調整し，個々の選手に とってブロックに力を加えやすい姿勢を取ってい たものと推察される．その結果，ブロッククリア ランスに拉いて加えられる力積とブロック配置と の間に相関関係がみられなかったものと考えられ る.

\section{4. スターティングブロックに加えられた力積} とクリアランス後のカ発揮の関係

図 4 より，スターティングブロックへの力積 の水平成分と第 1 歩目の力積の水平成分の間に は有意な負の相関関係 $(\mathrm{r}=-0.646, \mathrm{p}<0.01)$ が認められた。しかし, 第 1 歩目の力積の鉛直 成分との間には有意な相関関係は認められなかっ た（図 5)。また，表 6 よりブロッククリアラン ス中に加えられた力積の水平成分とブロッククリ アランス後の各時間との間には，後ブロックおよ び前ブロックへの力積の水平成分と滞空時間（後 ブロック $: \mathrm{r}=0.560, \mathrm{p}<0.05$; 前ブロック $\mathrm{r}=$ $-0.643, \mathrm{p}<0.05)$ との間に有意な相関関係が認 められたのみで，第 1 歩目の接地時間抢よび第 1 歩目離地までの時間にはいずれも有意な相関関係 は認められなかった。これらの結果から，ブロッ ククリアランス中に加えられた力積の大きさは, 第 1 歩目を接地するまでとは関係するものの, 第 1 歩目の接地以降には大きく関係しないと考 えられる.しかし，スターティングブロックへの 力積に限ってみると, 第 1 歩目の力積の水平成 分と有意な負の相関関係が認められており，ブロ ッククリアランス中に加えられた力積がクリアラ ンス後と全く関係しないとは言いきれない。

スターティングブロックへの力積の水平成分と 第 1 歩目の力積の水平成分との間に負の相関関 係がみられたことにより，スターティングブロッ 
クへの力積の水平成分と, 第 1 歩目の力積の水 平成分はどちらも大きくなる関係ではなかったこ とになる，中野ほか（1993）は，両足のブロッ クが揃ったジャンプスタートに関する研究を行 い, ブロッククリアランス時の速度は低いもの の，第 1 歩目から大きく加速ができるスタート であることを明らかにしている。このことは， 「ジャンプスタート」がブロッククリアランスで の速度獲得を大きくするものではなく, ブロック クリアランス後の第 1 歩目での速度獲得に重点 を置いたスタートとなっていたことを示すもので あると考えられる. 本研究では両足のブロックが 揃ったブロック配置であった者は抢らず，中野ほ か（1993）がいう「ジャンプスタート」を行っ ていた者はいなかった。そそのため, 中野ほか （1993）の報告と本研究の結果は単純に比較でき ないが，クリアランス時点での疾走速度をスター ティングブロックヘ加えた力積により生じたもの と捉える（Coppenolle et al., 1990）と，スターテ ィングブロックへの力積の水平成分と第 1 歩目 の力積の水平成分との間に負の相関関係がみられ たことは, ブロッククリアランスで大きく速度を 獲得して出発するか, ブロッククリアランス後の 第 1 歩目で獲得する速度を高めるか，その割合 が被験者によって異なっていたことを示す結果で あったと考えられる. また，スターティングブロ ックへの力積の大きさは時間の長さによるもので あったこと（表 3）から，ブロックから離れるま での時間が長くなっても, ブロッククリアランス での速度獲得を大きくするか, 早くブロックから 離れて，第 1 歩目での加速を大きくするか，と いうスタートでの加速方略が影響していたものと 考えられる.

このように，スターティングブロックへの力積 の水平成分と第 1 歩目の力積の水平成分の関係 から，ブロッククリアランスでの力発揮と第 1 歩目での力発揮は関係すると考えられるが，一方 で，第 1 歩目の力積の鉛直成分には有意な相関 関係が認められなかった（図 4, 図 5)。このこ とには, 個々の選手の第 1 歩目の接地スキルが 関係するものと推察される. 藤光 · 青山 (2009)
によると，ブロッククリアランス後の第 1 歩目 では足関節の角度变化に招ける変動係数が大き く, 動作の個人差が大きかったことが報告されて いる.さらに, この結果の背景については, キッ ク動作の技術的レベルが個人差として現れたもの としている。また，金子・佐藤（1999）による 々, 疾走動作接地中の地面反力の鉛直成分につい て, 足関節で発揮された関節トルクの貢献が他の 関節に比べて大きいという，つまり，足関節での 動作は加えられる力の鉛直成分に影響するものと 考えられる，これらの報告を踏まえると，第 1 歩目の接地中において, 主に足関節の動作の技術 的レベルが選手によって異なったことにより，第 1 歩目に加えられる力の鉛直成分に影響を及ぼし たことが考えられる.その結果, 第 1 歩目の力 積の水平成分と鉛直成分では, ブロッククリアラ ンス中に加えられた力積との相関関係の有無がそ れぞれで異なったものと考えられる.

以上のことから，ブロッククリアランスに抢け る力発揮の大きさは, ブロッククリアランス後の 第 1 歩目の力発揮と関係し, 中でも水平速度の 獲得に影響すると考えられる。したがって, 第 1 歩目を含めたスタートでの加速方略に合わせて, ブロッククリアランスでの力発揮を考える必要が あるといえる。

\section{5. スターティングブロックに加えられた力積 とパフォーマンスレベルの関係}

図 6 より，スターティングブロックヘの力積 の水平成分と $100 \mathrm{~m}$ 走自己記録との間には有意な 相関関係が認められた $(\mathrm{r}=-0.547, \mathrm{p}<0.05)$. しかし, 図 6 をみると, スターティングブロッ クへの力積の水平成分が最も大きい者が, 最もパ フォーマンスレベルが高いというわけではなかっ た.このことには第 1 歩目での力発揮が関係し ていると考えられる. 図 4 より, スターティン グブロックに加えられる力積が大きくなると, 第 1 歩目での水平方向への力積は小さかった $(r=$ -0.646, $\mathrm{p}<0.01)$. このことについては, 前節 でも述べたように，ブロッククリアランスで大き く速度を獲得して出発するか, ブロッククリアラ 
ンス後の第 1 歩目で獲得する速度を高めるか, 選手自身の加速方略に合わせてスタートしている ことが影響しているものと考えられる。したがっ て，パフォーマンスレベルの高い者は，スターテ イングブロックへの力積を大きくして, ブロック クリアランスで獲得する速度を高めながらも，続 く第 1 歩目での力発揮も含めた「スタート全体 としてのパフォーマンス」が高まるようにスター ティングブロックへの力発揮を行って，スタート しているものと考えられる.

\section{V.まとめ}

本研究では, 短距離走スタートに拈いてスター ティングブロックに加えられた力積をもとに，ス ターティングブロックへの力発揮の大きさとブロ ッククリアランス拈よびその後の第 1 歩目との 関係について検討を行った.

その結果，以下のことが明らかになった。

1） スターティングブロックへの力積の大き さから，ブロッククリアランスに抢ける力発揮は 水平成分（進行方向の成分）の力積によって特徵 づけられるものと考えられた。

2） スターティングブロックへの力積の大き さは，前ブロックへの力積の方が高い割合を占め るものの，その大きさの大小に影響するのは後ブ ロックへの力積であった.

3） スターティングブロックへの力積の大き さは，スターティングブロックに加えられた力の 大小よりも力を加える時間の長さにより影響を受 けるものであると考えられた。

4） スターティングブロックへの力積の大き さとブロック配置は大きく関係せず，選手と前後 のブロックとの相対的な位置関係が影響している ものと考えられた。

5） スターティングブロックへの力積の大き さは, ブロッククリアランス後の第 1 歩目での 水平方向への力発揮と関係していた。したがっ て，第 1 歩目を含めたスタートでの加速方略に 合わせて, ブロッククリアランスでの力発揮を考 える必要があると考えられた。

\section{文献}

Baumann, W. (1976) Kinematic and dynamic characteristics of the sprint start. In: Komi, P.V. (Ed.), Biomechanics V-B. University Park Press: Baltimore, MD: pp. 194-199.

Bender, W.R.G. (1934) Factors contributing to speed in the start of a race and characteristics of trained sprinters: A summary of experimental investigations. Research Quarterly, 5: 72-78.

Coppenolle, H., Delecluse, C., Goris, M., Diels, R., and Kraayenhof, H. (1990) An evaluation of the starting action of world class female sprinters. Track Technique, 90: 3581-3582.

Čoh, M., Jošt, B., Škof, B., Tomažin, K., and Dolenec, A. (1998) Kinematic and kinetic parameters of the sprint start and start acceleration model of top sprinters. Gymnica, 28: 33-42.

エッカー：佐々木秀幸 ·井街 悠訳 (1979) 運動力学 から見た陸上競技の種目別最新技術. ベースボール マガジン社 : 東京, pp. 27-41.

遠藤辰雄（1980）新体育学大系 第49巻：コーチ学 陸上競技編. 逍遙書院 : 東京, pp. 30-37.

Fortier, S., Basset, F.A., Mbourou, G.A., Favérial, J., and Teasdale, N. (2005) Starting block performance in sprinters: A statistical method for identifying discriminative parameters of the performance and an analysis of the effect of providing feedback over a 6week period. Journal of Sports Science and Medicine, 4: 134-143.

藤光謙司 · 青山清英（2009） スタートダッシュに抢け る疾走動作の変動特性に関する研究. 陸上競技研究, 76: 52-55.

Gambetta, V., Winckler, G., Rogers, J., Orognen, J., Seagrave, L., and Jolly, S. (1989) Sprint and Relays. In: Athletics Congress, Gambetta, V. (Eds.) The Athletics Congress's Track and Field Coaching Manual. Leisure Press: Champaign, pp. 58-60.

Guissard, N. and Duchateau, J. (1990) Electromyography of the sprint start. Journal of Human Movement Studies, 18: 97-106.

Harland, M.J. and Steele, J.R. (1997) Biomechanics of the sprint start. Sports Medicine, 23(1): 11-20.

Henry, F.M. (1952) Force-time characteristics of the sprint start. Research Quarterly, 23 (3): 301-318.

一川大輔·安井年文・高畠瑠依 (2006) スターティン グブロック設置方法に関する基礎的研究. 陸上競技 
研究, 67: 13-21.

金子今朝秋 · 小林一敏・勝亦紘一 (1976) 短距離スター トに抢けるキックと加速度. 日本体育学会大会号, 27: 315 .

金子靖仙・佐藤文宣（1999）走動作中の関節トルクの 地面反力への変換. 第14回日本バイオメカニクス学 会大会論文集 : 208-212.

片尾周造（1973）走運動に関する研究（技術指導面か らみたスタート動作について). 横浜市立大学紀要体 力医学編, 2(1): 1-11.

Kistler, J.W. (1934) A study of the distribution of the force exerted upon the blocks in starting from various starting positions. Research Quarterly Supplement, 5: 27-32.

小林 海 · 土江寛裕・松尾彰文・彼末一之・磯 繁 雄 · 矢内利政 · 金久博昭 - 福永哲夫 . 川上泰雄 (2009) スプリント走の加速局面における一流短距離 選手のキネティクスに関する研究. 早稲田大学ス ポーツ科学研究, 6: 119-130.

小林一敏 ·勝亦紘一 - 金子今朝秋 · 菅原秀二 (1975) スターティング・ブロックのキネシオロジー的研 究. 順天堂大学保健体育紀要, 18: 17-23.

Mach, G. (1985) The individual sprint events. In: Payne, H. (Ed.) Athletes in action: the official International Amateur Athletic Federation book on track and field techniques. Pelham Book: London, pp. 1234.

松尾彰文（2008）最大下スピード練習の効果を高める ための提案一ランニングパフォーマンスへの応用 一. 体育の科学, 58(11): 756-764.

Mero, A., Luhtanen, P., and Komi, P.V. (1983) A biomechanical study of the sprint start. Scandinavian Journal of sports sciences, 5(1): 20-28.

中野正英 · 尾縣 貢 ·阪口妙子 · 真野功太郎 (1993)

ジャプスタートの特徴に関する実験的研究. 陸上 競技研究，14: 22-29.

西内文夫（1979）陸上競技の技術（短距離）に関する 一考察. 体育研究, 13: 95-101.

野原弘嗣·花田 登·安里重則·山岡誠一 (1977) ク ラウチングスタートの研究. 京都教育大学紀要, 50-
B: $36-49$.

Payne, A.H. and Blader, F.B. (1971) The mechanics of the sprint start. In: Vredenbregt, J., Wartenweiler, J. (Eds.), Biomechanics II. Medicine and Sport Vol. 6 . Karger: Basel: pp. 225-231.

佐久間和彦・小林一敏（1980）：かかと浮きブロックと かかと着きブロックを用いた場合のスタート動作に 関するバイオメカニックス的研究. 順天堂大学保健 体育紀要, 23: 16-24.

Schot, P.K. and Knutzen, K.M. (1992) A biomechanical analysis of four sprint start positions. Research Quartly for Exercise and Sports, 63(2): 137-147.

シュモリンスキ一編：成田十次郎・関岡康雄訳（1982） ドイツ民主共和国の陸上競技教程. ベースボールマ ガシン社 : 東京, pp. 163-169.

篠原康男 · 前田正登（2010）短距離走におけるスター ティングブロックに加わる力の測定. 陸上競技研究, 80: 44-50.

袖山 紘 ·浅川正一 ·金原 勇 - 小佐文雄 (1969) ク ラウチングスタートの構えに関する基礎的研究. 体 育学研究, $13(5): 168$.

Tellez, T. and Doolittle, D. (1984) Sprinting from start to finish. Track technique, 88: 2802-2805.

戸倉広昌 ·佐藤 徹 (2009) 運動指導における運動感 覚の言語表現と動作共鳴一陸上競技のクラウチング スタートについて一. 北海道教育大学紀要（教育科 学編), 60(1): 203-213.

山根文隆 · 後藤幸弘 · 辻野 昭 - 梅野圭史 · 藤田定 彦・田中 譲 (1986) クラウチングスタート法の適 時性に関する基礎的研究一クラウチングスタート法 による効果の年齢差一. 第 8 回日本バイオメカニク 又学会大会論集 : 14-20.

湯浅撤平 (1976) 短距離: 陸上競技入門シリーズ(1). ベースボールマガジン社 : 東京, pp. 40-51.

$\left(\begin{array}{l}\text { 平成 } 25 \text { 年 } 2 \text { 月 } 15 \text { 日受付 } \\ \text { 平成 } 25 \text { 年 } 9 \text { 月 } 2 \text { 日受理 }\end{array}\right)$

Advance Publication by J-STAGE Published online 2013/10/11 